PRODUCTION

ENGINEERING

ARCHIVES
2014, Vol. 3, No 2, pp 31-34

ISSN 2353-5156 (print version)

ISSN 2353-7779 (online version)

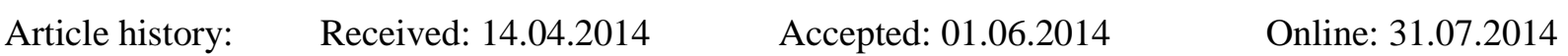

\title{
Influence of the welding process on martensitic high strength steel
}

\author{
Petr Hanus ${ }^{1}$, Michal Konečný \\ ${ }^{1}$ Univerzita of Pardubice, Studentská 95, 53210 Pardubice, CR, 724126098, petr.hanus@atlas.cz \\ ${ }^{2}$ Univerzita of Pardubice, Studentská 95, 53210 Pardubice, CR, konecnymichal@ volny.cz
}

\begin{abstract}
The subject of the study is martensitic 22MnB5 steels, which are used in the automotive industry. The main purpose of the performed analyses is a study of strength differences in heat affected zones of the spot welding. For the needs of the strength decrease assessment, the critical layer of the heat affected area was experimentally simulated. The aim of the work is to determine the most suitable methodology for evaluating the local changes of the elastic-plastic material response. The aim of this work is to determine the optimal methods for the determination of the yield strength and to find a firming trend in these zones.
\end{abstract}

Key words - Martensitic steel, dual phase steel, heat affected zones, yield strength, weld-joint fractures, indentation

\section{Introduction}

In order to provide the maximum safety for passengers alongside lowering the operational weight of vehicles, advanced high strength steels (AHSS) have recently been used during the production of car bodies. These groups of steels bring specific combinations of mechanical parameters and abilities of dynamic reinforcement together with keeping the tendency to ductile fracture in a wide range of working temperatures but also specific requirements for technological operations - primarily for forming and welding (TICHÝ J. 2006).

Martensitic 22MnB5 steel is a widely used steel grade in automotive application. Initially, the material exhibits a ferritic-pearlitic microstructure. After the hot stamping process, the components finally have a martensitic microstructure with a total strength of about $1500 \mathrm{MPa}$. In order to achieve martensitic micro- structure, the blank has to be austenitized in a furnace for at least $5 \mathrm{~min}$ at $950{ }^{\circ} \mathrm{C}$. The blank is formed and quenched simultaneously at a cooling rate of approximately $27 \mathrm{~K} / \mathrm{s}$. At a temperature of around $400{ }^{\circ} \mathrm{C}$, a diffusionless martensitic transformation will be induced, which finally is responsible for the resulting high strength of the part (KARBASIAN H., TEKKAYA A.E. 2010).

The employing of high strength steels includes two main problems. One of them is the research towards technological parameters of welding, which should suppress the undesirable strength loss inside the critical layers of joints. The other area is the necessity of registering the actually induced structural layer changes, which could influence the strength and the plasticity of the welded joints. The problem of the above stated high strength steels lies mostly in the tendency for a local loss of the distributive strengthening together with the undesirable tempering of the martensitic element, obtained through the specific 
technological procedures of semi-finished product processing.

The aim of the presented work is to find a new way for the evaluation of the softening process intensity due to applied spot welding technology. The comparative tensile tests were used for experimental evaluation of the methodology used.

\section{The experimental assessment of the heat loading influence}

The samples for experimental examination (chemical composition in the Tab. 2.1) were prepared from the $22 \mathrm{MnB} 5$ steel with $15-20 \mu \mathrm{m}$ thick Al-Si anticorrosive surfaces, which ensure corrosion protection during hardening by moulding.

In practice, these materials are jointed by resistance spot welding. But the high initial material strength and the presence of the above mentioned surface treatment, especially the Al-Si layer, bring specific conditions for acquiring a first-rate joint. Tests proved that it is primarily the thickness of the silicon enriched interlayer on the border of the base material which is limiting for weldability. With the change of the interlayer silicone rich sub-layers thickness, gradual iron saturation appears. Consequently, this effect seems to be substantial for weldability (SCHMIDOVÁ E., KoneČnÝ M. 2009, Schmidová E., HANUS P. 2013).

Table 1. The basic composition of martensitic steel material

\begin{tabular}{|c|c|}
\hline Sample & 22MnB5 [wt\%] \\
\hline $\mathbf{C}$ & 0.25 \\
\hline $\mathbf{M n}$ & 1.25 \\
\hline $\mathbf{S i}$ & 0.25 \\
\hline $\mathbf{P}$ & 0.02 \\
\hline $\mathbf{S}$ & 0.002 \\
\hline $\mathbf{C r}$ & 0.2 \\
\hline $\mathbf{N i}$ & 0.01 \\
\hline $\mathbf{C u}$ & 0.02 \\
\hline $\mathbf{A l}$ & 0.04 \\
\hline $\mathbf{T i}$ & 0.04 \\
\hline $\mathbf{B}$ & 0.004 \\
\hline
\end{tabular}

Source: own study.

\subsection{The simulated heat loading}

The assessment of the elastic-plastic behaviour of the strength loss layers was based on the simulated heat loading of the samples, which were tested by the standard tensile tests. The shape of the samples was adapted in order to enable the heat loading simulation process (Fig.1). The samples were cut from flat carbody parts intended for spot welds.

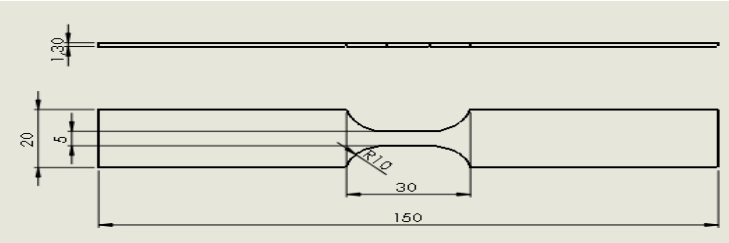

Fig. 1. The shape of the sample.

Source: own study.

With the aim of simulating the heat strain just like in the case of spot welding, the samples were subject to the heat loading induced by:

- resistive heating accelerated by air cooling: $\mathrm{C} 01$, $\mathrm{C} 02, \mathrm{C} 03$

- resistive heating not accelerated by air cooling: N01, N02, N03

- $\quad$ spot welded: B01, B02, B03

The main emphasis was put on reaching limit sample temperatures below $707^{\circ} \mathrm{C}$, which is the critical temperature of the examined materials. This temperature was obtained from this relationship (ELBEL T. 1980):

$\mathrm{A}_{\mathrm{c} 1}=721-14 \% \mathrm{Mn}+22 \% \mathrm{Si}-14,4 \% \mathrm{Ni}+23,3 \% \mathrm{Cr}\left[{ }^{\circ} \mathrm{C}\right]$

Cooling rate curves are shown in the Fig.2
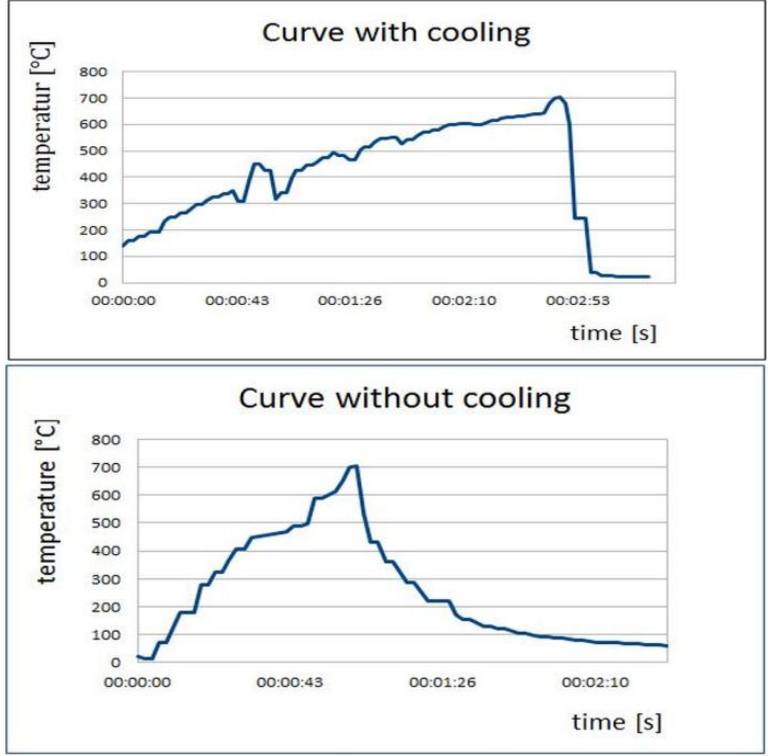

Fig. 2. Cooling rate.

Source: own study. 


\subsection{The range and the intensity of the heat influence}

Verification of the proper level of tempering was based on the hardness measurement. This measurement was precise enough to detect local differences of the individual heat affected zone sub-layers (Fig.3).

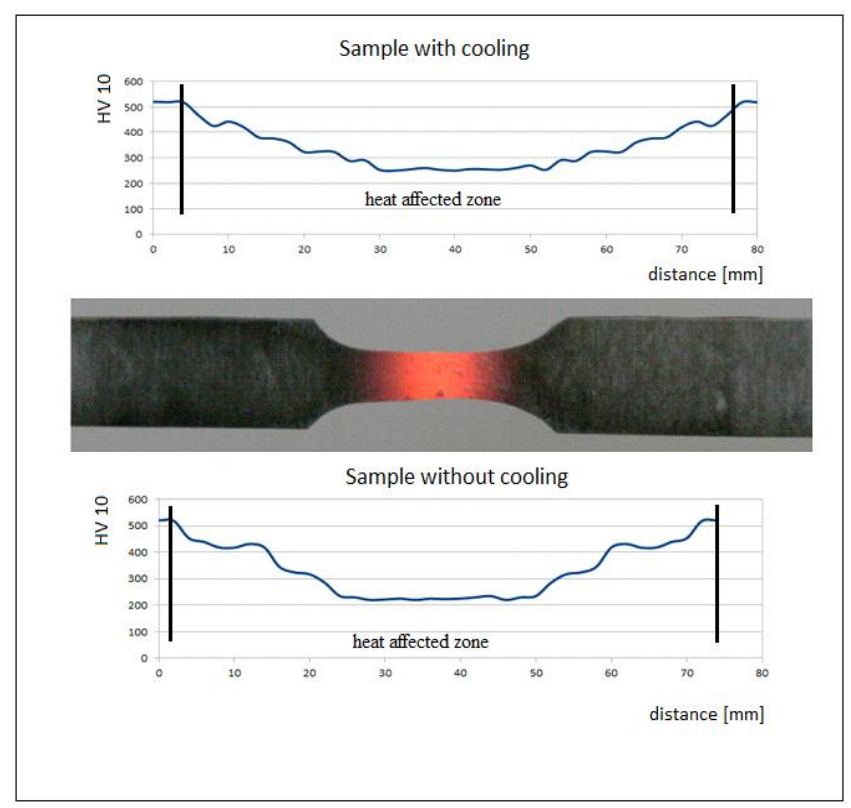

Fig. 3. Changes microhardness in heat affected zones

Source: own study.

The resultant hardness loss of the samples, presenting the influence of the spot weld, is displayed in the Tab.2. During the measurement, almost stable values of the highest strength loss were observed in the affected area in comparison with the simulated heat influence, see in the Tab.2.

Table 2 Values of the highest strength loss

\begin{tabular}{|l|l|l|l|l|l|l|l|l|l|}
\hline Sample & N01 & N02 & N03 & C01 & C02 & C03 & B01 & B02 & B03 \\
\hline HV 10 & 218 & 217 & 220 & 235 & 237 & 232 & 235 & 240 & 232 \\
\hline
\end{tabular}

Source: own study.

\subsection{The application of the indentation method of the strength differences evaluation}

As yet another source of information which can describe the changes of the mechanical properties in the critical areas, the indentation method can be used.
The standard way of measuring is the Martens hardness, however, it does not enable the straightforward evaluation of the elastic-plastic material response because there is a significant influence of the contact surface change of the indentor during loading. In order to authenticate the measurement possibilities of the local changes of the mechanical properties with this method, a cylindrical indentor with a diameter of 1,5 mm was used.

The methodology is based on the assessment of the loading part of the indentation curve. From the 2nd derivation, we can obtain the inflection point, (Fig.4), whose coordinates correspond with the force necessary to reach the yield strength (BREAK THROUGH INDENTATION YIELD STREGHT TESTING 2011).

From the series of the measured indentation curves, there was a difference in the beginning of the loading curve record. The difference is repeated in each indentation with a different shape and inclination. We consider the influence of:

- the surface deformation of the sample during the tool application

- the deformation of the intendor

- high requirements on surface quality for the method application

The cylindrical indentor was applied to the areas of the simulated heat influence. When the size of the tool is considered, it was only possible to use the samples which were subjected to the heat loading in the furnace or resistive-heating.

The values of the yield strength obtained by the indentation test and compared to the values obtained by the pull test show the maximum dispersion of about $3 \%$ (Tab.3).

Table 3. Indentation Method vs. Method Yield Strength

\begin{tabular}{|c|c|c|c|}
\hline Sample & $\begin{array}{c}\text { Inflection } \\
\text { Point [N] }\end{array}$ & $\begin{array}{c}\text { Indentation } \\
\text { Method [MPa] }\end{array}$ & $\begin{array}{c}\text { Yield Strength - } \\
\text { tensile test [MPa] }\end{array}$ \\
\hline C01 & 1100 & 760 & 780 \\
\hline C02 & 1050 & 700 & 680 \\
\hline C03 & 1080 & 720 & 675 \\
\hline N01 & 1120 & 631 & 615 \\
\hline N02 & 1140 & 715 & 724 \\
\hline N03 & 1150 & 730 & 753 \\
\hline
\end{tabular}

Source: own study. 


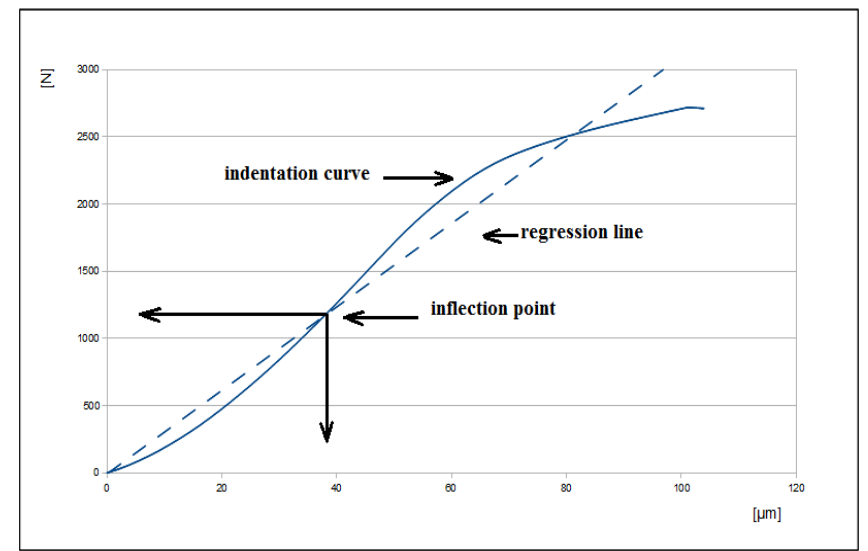

Fig. 4. Process of indentation method

Source: own study.

\section{Conclusions}

The spot welding of the high strength steels brings problems related to the decrease of strength in the critical heat affected zone. The intensity of the strength loss and the joint geometry influence the strength of the joints as well as the energy consumption of the dynamic endurance of welds.

This work presents the input experiments with the aim of setting a methodology which would lead to an assessment of the mechanical property changes which appear during the heat loading. The performed experiment is oriented to the evaluation of the yield strength with the help of the indentation methods. As a verification of the methodology, there is the comparison of the indentation method and the tensile data, which were converted into the real ones.

The tool for the indentation method was the cylindric indentor with a diameter of $1,5 \mathrm{~mm}$, which later led to the need to simulate the heat affected areas.

The results presented suggest the methodology used as a possible way to solve the problem; for true validation of the methodology a higher number of tested samples is needed.

In order to test the local areas of the examined materials, which are at intervals around $200 \mu \mathrm{m}$, it is necessary to create an indentation tool whose diameter is smaller than the affected zone.

The results confirm good prospects for the method which would enable the assessment of the strength differences in the narrow heat affected zone. For the needs of the numeric prediction of the static strength of welds, it is also necessary to verify abilities of the above stated method for the evaluation of the plastic area of the loading, i. e. the differences in the mode of deformation hardening.

\section{References}

1. TICHÝ J. 2006. Svařování v automobilovém průmyslu -2. 34ast. Časopis Svět svaru, Ostrava, s. 14-15.

2. Karbasian H., TeKkaya A.E. 2010. A review on hot stamping. Journal of Materials Processing Technology 210, 2103-2118.

3. Schmidová E., Hanus P. 2013. Problems of Spot Welding of Al-Si Coated Martensitic Low Alloyed Steels, $30^{\text {th }}$ Intermational Colloquium on Advanced Manufacturing and Repairing Technologies in Vehicle Industry, Visegrád, Hungary, 22-24 May, ISBN 978963-313-079-7

4. Schmidová E., KoneČnÝ M. 2009. Parameters of the Quality of Welding High Strength Materials. In Production engineering. Novosibirsk: Novosibirsk State Technical University, , s. 151-159. ISBN 978-5-7782-11650 .

5. Elbel T. 1980. Výpočet intervalu teplot tuhnuti u uhlikových a nízkolegovaných ocelí. Slévárenství,XXVIII, s.318

6. CSN EN ISO 10275 2008. Kovové materiály - Kovové materiály -Stanovení exponentu deformačního zpevnění tahem, Leden. 31s.

7. BREAK THROUGH INDENTATION YIELD STREGHT TESTING [online] Dostupné z WWW:

$<$ http://www.nanovea.com/MechanicalTesters.html > [cit . 6.2011] 